\title{
QUEEN'S
UNIVERSITY
BELFAST
}

\section{A Four-Nation Comparison of Kinship Care in the UK: The Relationship between Formal Kinship Care and Deprivation}

McCartan, C., Bunting, L., Bywaters, P., Davidson, G., Elliott, M., \& Hooper, J. (2018). A Four-Nation

Comparison of Kinship Care in the UK: The Relationship between Formal Kinship Care and Deprivation. Social Policy and Society. https://doi.org/10.1017/S1474746418000179

\section{Published in:}

Social Policy and Society

\section{Document Version:}

Peer reviewed version

Queen's University Belfast - Research Portal:

Link to publication record in Queen's University Belfast Research Portal

Publisher rights

(c) 2018 Cambridge University Press.

This work is made available online in accordance with the publisher's policies. Please refer to any applicable terms of use of the publisher.

\section{General rights}

Copyright for the publications made accessible via the Queen's University Belfast Research Portal is retained by the author(s) and / or other copyright owners and it is a condition of accessing these publications that users recognise and abide by the legal requirements associated with these rights.

Take down policy

The Research Portal is Queen's institutional repository that provides access to Queen's research output. Every effort has been made to ensure that content in the Research Portal does not infringe any person's rights, or applicable UK laws. If you discover content in the Research Portal that you believe breaches copyright or violates any law, please contact openaccess@qub.ac.uk. 
A Four-Nation Comparison of Kinship Care in the UK: The Relationship between Formal Kinship Care and Deprivation

\section{Claire McCartan*, Lisa Bunting ${ }^{* *}$, Paul Bywaters ${ }^{* * *}$, Gavin Davidson ${ }^{\dagger}$, Martin Elliott ${ }^{\ddagger}$ and Jade Hooper ${ }^{\S}$}

*School of Social Sciences, Education and Social Work, Queen's University Belfast

E-mail: c.j.mccartan@qub.ac.uk

${ }^{*}$ School of Social Sciences, Education and Social Work, Queen's University Belfast

E-mail: I.bunting@qub.ac.uk

${ }^{\star * *}$ Centre for Applied Childhood, Youth and Family Research, University of Huddersfield

E-mail: p.bywaters@hud.ac.uk

${ }^{\dagger}$ School of Social Sciences, Education and Social Work, Queen's University Belfast

E-mail: g.davidson@qub.ac.uk

${ }^{\ddagger}$ CASCADE, School of Social Sciences, Cardiff University

E-mail: elliottmc1@cardiff.ac.uk

${ }^{\S}$ Faculty of Social Science, University of Stirling

E-mail: jade.hooper@stir.ac.uk

The practice of extended family and friends helping to care for children when their parents are unable to is an enduring tradition in many cultures. Kinship care provides the largest proportion of out of home care in Western society but many of these carers experience poverty and deprivation, and do not receive comparable levels of support, financial or professional, to other placement types. This study provides UK evidence for the relationship between kinship care and deprivation and examines how the welfare state frames kinship care in policy and practice.

Keywords: Child welfare, looked after children (LAC), deprivation, four nation, kinship care. 


\section{Introduction}

The traditional concept of the nuclear family no longer reflects the diverse range of social structures considered to be 'family' in Western society. With rising rates of unmarried cohabitating couples, divorce, lone parents, same sex couples and reconstituted families, modern family composition is not always biological (Weeks et al., 2003) but takes many forms. While fewer families are living together intergenerationally (Cheal, 2008), people still rely on extended family and friendship networks to provide child and elderly care, emotional and financial support. This demonstrates the strong social bonds of family and a lasting tradition of kinship care in many cultures, but also reflects current social work practice. This article presents analysis of four nation child welfare administrative data and explores whether formal kinship rates vary between the four UK countries and whether deprivation influences this placement type. It will detail the association between kinship care and deprivation and discuss how the state differentiates financially between kinship care and other types of looked after provision for children in need. Failure to adequately acknowledge the considerable burden, complexity and responsibility of kinship care disadvantages these families and policy should be reviewed to reflect and secure appropriate resources and support for all kinship carers.

\section{Background}

The typology proposed by Esping-Andersen (Esping Andersen, 1990) characterised the UK's liberal welfare state as having minimal decommodification (replacement of market earnings), the provision of stigmatising means-tested benefits, and a reliance on the market to provide welfare. This is in contrast to: the Scandinavian social-democratic model (generous decommodification, and tax-funded universal benefits); and the Continental European Conservative World (varying levels of decommodification and reliance on family for welfare). Although Esping-Andersen's typologies have been criticised on the grounds of being gendered (Lewis, 1998) and for distilling eighteen OECD countries into three regimes (Arts and Gelissen, 2002), this description of the UK's welfare state has some resonance today. Hantrais' (Hantrais, 2004) analysis of EU member states identified four types of familialisation 
in welfare regime, describing the UK as 'defamilialised' - whereby macro national welfare measures e.g. maternity pay and child benefit, grant a degree of independence from family and kinship networks. However, in practice, when families are in crisis, there is evidence of 'refamilialisation' at macro (government policy), meso (local authority policy) and micro (individual social work practice) levels, and of an increasing reliance on extended families and friends to provide care for looked after children. Some of this kinship care provision is arranged formally under the auspices of the state, but the vast majority is provided under private, voluntary arrangements between the parent and the kinship carer which does not provide the same safeguards that formal placements provide. It is a requirement of the Children Act 1989, that local authorities consider kinship care before placements with unrelated carers for a number of reasons: (1) it is considered better to keep a child within the extended family, (2) in a setting which is probably familiar to the child; (3) the placement outcomes are often better; and (4) it is the most cost-effective and time efficient placement option for a social worker. When the state intervenes to support a family at risk, friends and relatives are more often the first (and only) source of support and one which the state relies heavily upon. However, as Hantrais states, the family is one of the most basic forms of social integration, and the state must have policies that address the wellbeing of families; current practice does not necessarily reflect this for kinship carers.

Kinship care is the most prevalent form of alternative out of home care in Western society (Andersen and Fallesen, 2015, Connolly et al., 2017) but has been described as the 'Cinderella' of the care system (Kiraly, 2015). Providing 20 times the level of state care in the UK (Kiraly, 2015), data from the 2001 census estimated that around 173,200 children were living in kinship care in the UK (Selwyn and Nandy, 2014). Kinship care arrangements can be 'formal' (the local authority responsible for the child assesses and approves carers who will be entitled to financial and other support) or 'informal' (typically resulting from a private arrangement between the parent and kinship carer) (Selwyn and Nandy, 2014). Complying with the UK's commitment to the UNCRC's 'right to a family/family life' (United Nations, 1989), it is endorsed as the preferred care option in law (Daly and Perry, 2011, Lin, 2014): the 
Children Act 1989; the Children (Northern Ireland) Order 1995; Scotland Act 1995; the Adoption and Safe Family Act 1997.

The legal framework for kinship care in England, Wales and Northern Ireland (NI) is similar. There is no requirement to notify the local authority if a child moves to live with a relative for care. If the carer is not a relative, the child is under 16 (or 18 if disabled) and the placement lasts longer than 28 days, the placement is considered as private fostering (Children Act 1989; the Children (Northern Ireland) Order 1995; Children (Private Arrangement for Fostering) Regulations 2005). In Scotland, the Guidance on Looked After Children (Scotland) 2009, acknowledges the many informal kinship arrangements where a child has no legal relationship with a local authority. Regulations do not apply to informal arrangements. Scotland differs to the other nations whereby a kinship carer not only includes siblings, aunts, uncles, and grandparents but cousins, and more distant relatives and friends. Different terminology and assessment processes are applied in each of the four nations. In England and Wales, non-relative foster care (NRFC) and kinship carers are formally assessed against the same standards. In NI and Scotland the term 'kinship care' applies, but there are specific standards (DHSSPS, 2014) The Looked After Children (Scotland) Regulations 2009, SSI/210). Financial support is not means tested, but rests on the legal status of the placement; only registered foster carers are entitled to support and not all kinship carers can meet local authority conditions. In 2017 it was estimated that only 3.5 per cent of the 180,000 children in kinship care were legally entitled to financial and professional support. A high court ruling in 2013 stated that local authorities should follow statutory guidance so that kinship foster carers would not be paid less than NRFC but informal kinship carers were not included as part of this ruling (Davey, 2016). In 2015, the Scottish Government made available additional funding 'to ensure local parity of allowances between kinship and foster carers' (Scottish Government, 2015) and although this has extended to some types of informal kinship care, it is not universal. This may contribute to the evidence that local authorities have a vested interest in not approving kinship carers as kinship foster carers (Hunt and Waterhouse, 2013, Selwyn et al., 2013). Failure to be approved has led to carers being unaware of their entitlements and a 
reluctance of child welfare workers to advise carers of the money and support available (Cox, 2014, Farmer and Moyers, 2008). While there is variation at macro policy level, there is evidence too of different policy at a meso level and a 'great variety of practice in different local authorities with regard to kinship care' (Kidner, 2012: 1).

Despite these differences, UK policy has experienced a convergence over the last ten years focusing on early intervention, placement permanency with extended use of kinship placements and using adoption as a means of exiting care (McGhee et al., 2017). NI, Scotland and Wales have also seen the number of very young children entering care rise; this has not been the case for England. The significant increase in the number of kinship carers in recent years (Houston et al., 2017) has been associated with a rise in reported cases of abuse and neglect, higher numbers of children entering care and a declining foster carer population unable to meet demand. Kinship care is cheaper than regular foster care, requires less formal training (Farmer and Moyers, 2008) and is likely to build on a pre-existing bond with the child who may have spent a considerable amount of time with kin prior to the placement (Brown et al., 2002, Font, 2015).

Grandparents typically comprise the largest group of kinship carers and this trend has risen steadily over the last 20 years (Kreider and Ellis, 2011). As a result, kinship carers are more likely to be older (Ehrle and Geen, 2002, Harnett et al., 2014), experience poverty and deprivation (Sakai et al., 2011, O'Leary and Butler, 2015), and suffer from stress and other health-related concerns (Cox, 2014, O'Leary and Butler, 2015). They often support children that have faced multiple adversities but may not receive appropriate resources to provide for the children in their care (MacDonald et al., 2018). Kinship care arrangements are frequently characterised by sudden and crisis-point placements with little preparation, advice or information made available to the carer (Denby, 2016). Placements can be complex and create tensions with the child's biological parents and the wider family network (Peterson and Starks, 2014, O'Leary and Butler, 2015) and establishing relationships with statutory services can also be complicated due to the informal nature of the care arrangement (Selwyn and Nandy, 2014). Despite all these difficulties, these non-traditional family constructs can provide 
caring, family environments with greater placement stability than other types of care (Font, 2015, Bell and Romano, 2017) in a family that is not defined by household structure or biology but by demonstration of family practices (Morgan, 2011).

\section{Outcomes for children in kinship care}

Kinship care can be good for children. In the US, confirmed cases of maltreatment are significantly underrepresented in kinship care homes (Zuravin et al., 1993, Testa et al., 2010), they offer more stable placements than NRFC (Koh, 2010, Font, 2015, Winokur et al., 2018). For children who have been maltreated, kinship carers also tend to provide a secure and safe environment with beneficial treatment (Herring et al., 2009) with a lower chance of re-entering foster care (Koh, 2010). It is thought that the transition to kinship care is less traumatic (Messing, 2006), children are much happier and experience less stress (Broad, 2004, Aldgate, 2009) and UK kin carers have found to have higher levels of commitment to the placement (Farmer, 2009).

There is however also evidence of negative outcomes. Children may be less likely to be reunified with their birth family (Farmer, 2009, Taussig and Clyman, 2011) and US research found that more time in kinship care can be associated with substance abuse, delinquency and poor academic performance (Ryan et al., 2010, Taussig and Clyman, 2011, Font, 2015). Continued contact with a birth parent may not always be in the child's interest, and can create conflict and potentially expose the child to ongoing abuse (Wellard et al., 2017, Breman et al., 2018). Kinship carers can underplay behavioural difficulties and this could have negative outcomes for assessing special needs or disability (Breman, 2014, Mitchell, 2014). Children living with kin are more likely to experience traumas associated with abuse, neglect or parental abandonment but, despite this, may not receive, or are ineligible to avail of, a range of supports including: specialised health, mental health, school-related services or clothing allowances which are more available to children in state care (Geen, 2002). Understanding government benefits and entitlements, and navigating community services and resources, can be difficult and carers can be embarrassed to ask for help (Fruhauf et al., 2015). Kinship carers undertake 
a duty of care and social responsibility for children in need, but the state does not appear to adequately address the welfare needs of either the child or the kinship carer. While poverty remains the single most important driver of a child's health and wellbeing, social work policy and practice has not addressed this effectively (Davidson et al., 2017).

\section{Kinship care - multiple layers of disadvantage}

Despite being the state's preferred option to provide out of home care, kinship care is characterised by deprivation on multiple levels. It is disproportionate to NRFC in terms of financial maintenance, social and emotional support services, and the range of personal economic and social challenges can be much greater. There has been criticism too that it is not always regarded by child welfare professionals as a serious alternative to formal placements (Corbin, 2015). Research in Denmark and the US found that kinship carers are more likely to live in poverty than NRFCs and receive, on average, less financial support from government reinforcing economic disadvantage (Andersen and Fallesen, 2015, Berrick and Hernandez, 2016). NRFC are twice as likely as kinship carers to obtain financial assistance, and four times more likely to receive respite or peer-support services (Sakai et al., 2011). Financial regimes for kinship carers in the UK vary depending on whether the child is formally looked after by a local authority and variation in payment of allowances is not uncommon (Kidner, 2012, Wade et al., 2014). Evidence from Australia (Breman, 2014) suggests that the current funding model is based on the assumption that most placements only require low level support. This two-tiered system, evident in many countries, offers more support to NRFC and undervalues the important role that kinship care provides to both the state and children in need.

Kinship carers are more likely to live in disadvantaged neighbourhoods, public or overcrowded housing (Cox, 2014, Andersen and Fallesen, 2015). Grandparents providing kinship care for children are often economically vulnerable and have the highest rates of poverty of any housing type (Kreider and Ellis, 2011). Many need to dramatically re-evaluate their economic situation once they become carers, return to work, work much longer hours 
than their peers and postpone retirement (Bailey et al., 2013, Brennan and Cass, 2014). Those living in rural communities face further challenges because there are fewer community resources, transportation and social isolation. They also have poorer access to childcare, limited support services, foodbanks, job opportunities and mental health services (Kropf and Robinson, 2004, Probst et al., 2004).

The cost differential between kinship care and NRFC makes it a desirable option for the state when funding is tight. Placement start-up costs are lower, there are no recruitment costs, less training is required and typically less support is offered once a placement is established (Berrick and Hernandez, 2016). Kinship care clearly can be 'financially attractive for cash-strapped local authorities' (McGhee et al., 2017: 17). Kinship networks are not only relied upon to provide emotional support but also offer crucial financial assistance. Daly and Kelly's (2015) work on poverty provides evidence for the economic reliance on extended family necessitated by hardship. In the absence of the state providing adequate support, family is often the only other source of help.

\section{Methods}

Child welfare inequalities occur 'when children and/or their parents face unequal chances, experiences or outcomes of involvement with child welfare services that are systematically associated with structural social disadvantage' (Bywaters et al., 2015: 100). Routinely collected UK child welfare administrative data have their limitations; little or no information about the child's parents is recorded, some of the data are low quality (e.g. disability and ethnicity recording), and the smallest geographies available are at local authority level. There is also some regional variation on how child welfare interventions are recorded for children who are the subject of a substantiated child protection concern or are being looked after. In $\mathrm{NI}$, Scotland and Wales, child protection registers (CPR) record children who have been identified as at risk of significant harm, these children will then be subject to a child protection plan (CPP). England does not keep a register, but places all children deemed to be at risk on a CPP. Different recording procedures are also used for categories of abuse. The Child 
Welfare Inequalities Project (CWIP) set out to detail the relationship of deprivation, policy and other factors to inequalities in key child welfare intervention rates through separate and comparative studies in the four UK countries.

Following evidence from a pilot study in England (Bywaters et al., 2016a), we wanted to find out if a child's chances of becoming looked after, or subject to a child protection plan/register, were systematically linked to where they lived in the UK. The research set out to ask if child welfare intervention rates and patterns vary between the four UK countries, and if rates and patterns vary within countries. This was done using a mixed-methods approach. Firstly, by linking and conducting secondary analysis of administrative data of child welfare statistics, child population data and deprivation data (a full description of the methodology is detailed elsewhere (Bywaters et al., forthcoming)). Secondly, a mixed methods case study approach was used to explore social work discourses around poverty and deprivation in comparative sites in England and Scotland, as described in Walsh and Mason (2018).

In order to examine child welfare rates by area level deprivation, data were requested for all children aged 0-17 years who were on a Child Protection Plan (CPP), the Child Protection Register, or were LAC on the census date, 31 March 2015 (31 July 2015 in Scotland). As postcode data is not routinely collected for CPP, individual approaches were made to each local authority in England, Scotland and Wales to request this information. This was a lengthy and often individualised process with each authority having different data access agreement procedures to comply with. In NI, the Honest Broker Service (a central repository providing anonymised ethnically approved health and social care data routinely collected by the DHSSPS) was able to link and provide all data requested. All NI analysis had to be conducted onsite within the HBS safe haven, with all intermediate and final outputs approved by their team. A considerable amount of time was spent cleaning and formatting the data with the English quantitative team taking the lead in data preparation procedures, data management and the cross-country analysis plan.

The sampling strategy for England and Scotland was designed to secure a representative sample of children subject to child welfare interventions, of sufficient size and 
from enough local authorities to investigate patterns of intervention. In England, we aimed to include a minimum of 10 per cent of all children and 10 per cent of all local authorities from an equal representation of low, medium, and high average deprivation scores. This strategy achieved a sample of 12.4 per cent of all children aged 0-17 years, 13.5 per cent of CPP and 12.7 per cent of LAC (total of 18 LAs). The Scottish sampling strategy was designed to include a minimum of 50 per cent of all children in at least 10 of 32 LAs, including four of the five largest LAs. A total population was used in $\mathrm{NI}$ and Wales. In total, data from $55 \mathrm{LAs} / \mathrm{Health}$ and Social Care Trusts were collected and analysed using the UK index that was developed. Cleaned data were compared to official publications and some small variations were found which were attributed to the use of aggregate returns and recording conventions in some areas.

Small geographies were used to describe neighbourhood characteristics: England and Wales - Lower Super Output Areas (average population 1600); NI - Super Output Areas (average population 2000), and; Scotland - Data Zones (average population 800). Each of these geographies were linked to an Index of Multiple Deprivation (IMD) score, and rank, within each country. Each nation has developed their own index of multiple deprivation and variations in the methods used included: weighting of the indicators; the time periods these cover; and the sizes of the small area means. The four national Deprivation Indices are updated at different times, our analysis was based on England (2010), NI (2010), Scotland (2012), and Wales (2014). This can create difficulty making direct comparisons between countries (Department for Communities and Local Government, 2016). To account for these differences, we applied a methodology established by Payne and Abel (2012). This approach adjusts each country's IMD score based on the IMD employment and income domains and, using linear regression modelling, generates an overall IMD score to create consistent UKwide estimates of deprivation. This method was used to score and rank small level geographies to a UK-wide index of Index of Multiple Deprivation, to support the cross-country comparisons. Within country analyses were based on each country's IMD. 
We examined country and UK level data by area deprivation and different placement type (all LAC, children accommodated by the local authority, children living with parents/relatives/friends), gender, age, ethnicity (the count of ethnic minorities was too small to be analysed in NI but religious background was also analysed) and by local authority or HSCT (Health and Social Care Trust). Kinship care included all children living with relatives or friends (children living with parents were removed from the Scottish count). Analysis was conducted using IBM SPSS, Version 24. Rates were adjusted to account for missing data in England and Scotland. It is also important to note that no neighbourhoods in NI were ranked in the most affluent ten per cent in the UK.

\section{Limitations of the study}

The measures we used to describe maltreatment and poverty have some limitations. In the absence of data on rates of abuse and neglect, child welfare intervention rates provide an imperfect proxy for maltreatment; the IMD also provides an improper proxy for poverty because it measures relative deprivation, identifying whether any given area is more or less deprived than another. Postcode data used to measure area level deprivation was derived from the child's family of origin address, and not that of the kinship carer, however, it is likely that their material circumstances are similar. It is also important to note that the data describe those children living under formal kinship arrangements and the large majority of children living with friends and relatives do so on a voluntary, informal basis.

\section{Findings}

\section{LAC and kinship care rates per 10,000 children}

Figure 1 shows that rates of formal kinship care were much higher in Scotland (49 per 10,000 children) and $\mathrm{NI}$ (39) than in England (7) and Wales (14). Accounting for higher LAC rates overall, the use of kinship care in NI (31 per cent of all LAC) and Scotland (29 per cent) was much higher than in England (16 per cent) and Wales (11 per cent). There could be a number of reasons why rates are much lower in England and Wales compared to Scotland and $\mathrm{NI}$ 
although they do reflect a trend over the last ten years where rates have remained fairly stable in England and Wales, and rates in Scotland and NI have continued to rise (McGhee et al., 2017).

Figure 1. LAC/Kinship Care Rate per 10,000 0-17 year olds

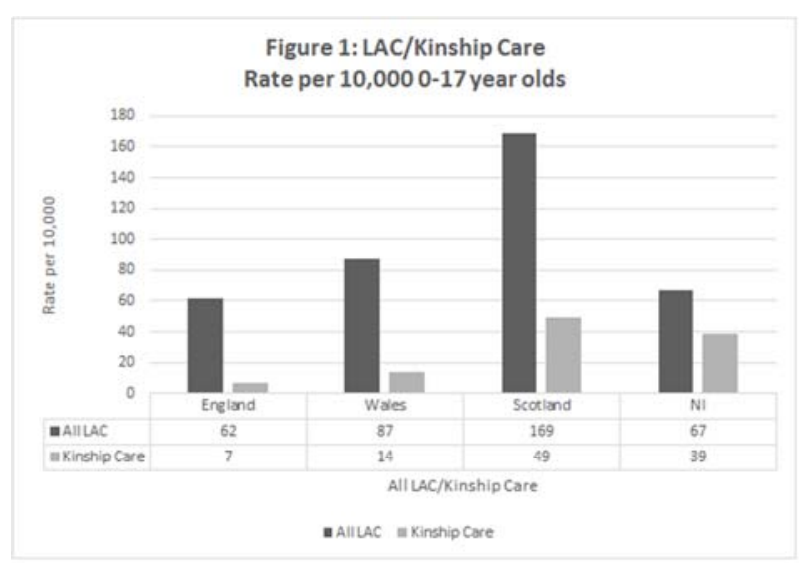

The LAC rates in Scotland are much higher than the other nations. Even when LAC rates were compared for children who were not living with a parent/relative/friend, a child living in Scotland was 57 per cent more likely to be a LAC than in England (Hooper et al., 2017). Additional analysis of the use of permanence orders in Scotland did not account for the higher rates. Operationally, while England, $\mathrm{NI}$ and Wales use the Family Law Courts for child protection legal interventions, in Scotland the Children's Hearing System provides a nonadversarial tribunal setting to make decisions about child protection concerns (McGhee and Waterhouse, 2012). Nl's integrated health and social care system, and the impact of culture and politics may also contribute to higher rates of kinship care. There is some complexity associated with making direct comparisons between kinship care rates across the UK due to: the different thresholds and mechanisms for assessing and approving NRFC/kinship care 
across nations (McGhee et al., 2017); and definitional differences or variations in social work practice (Bywaters et al., forthcoming). Despite these differences, a trend was still observed.

Kinship care as a proportion of the LAC population and deprivation As Figure 2 shows, the use of kinship care as a proportion of the total looked after population by deprivation decile was relatively stable across each decile for England, ranging from between 10 and 16 per cent of the total LAC population. Deprivation did not influence placement choice in England. The proportion of LAC who were in kinship care was greater in more deprived deciles in Wales and ranged from nine to 21 per cent. In Scotland (a range of 18 to 32 per cent) and Northern Ireland, (a range of 13-36 per cent), a general upward trend was observed between deprivation and higher rates of kinship care. Kinship care formed the largest proportion of looked after children placements in $\mathrm{NI}$ and the highest percentage use of kinship care within LAC compared to the other nations.

Figure 2. Kinship Care as a Percentage of LAC by Deprivation Decile

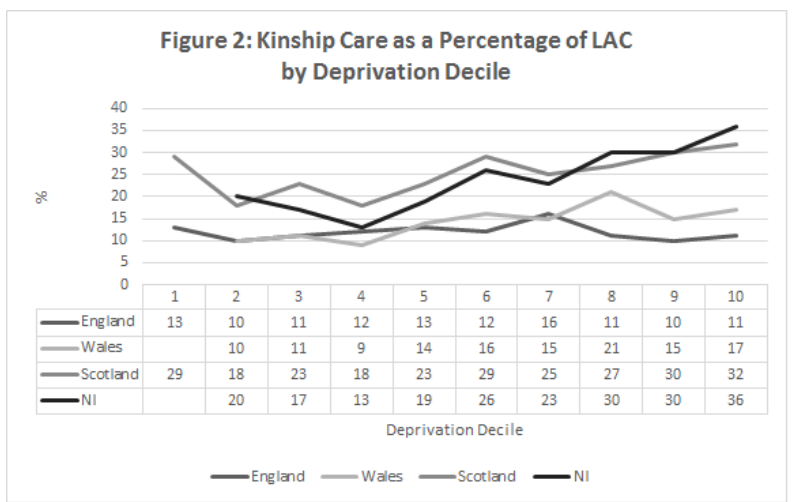


Rates of kinship care by deprivation decile

We then looked at the relationship between deprivation and kinship care and a positive relationship was observed across all four nations (Figure 3). The chances of a child entering kinship care were much greater in the 10 per cent most deprived neighbourhoods in each nation. Ranging from an 8 times greater chance in England, 22 times in Scotland, and 40 times greater chance in both Wales and $\mathrm{NI}$ than in the least deprived 10 per cent of neighbourhoods.

Figure 3. Rates of Kinship Care per 10,000 0-17 year olds by Deprivation Decile

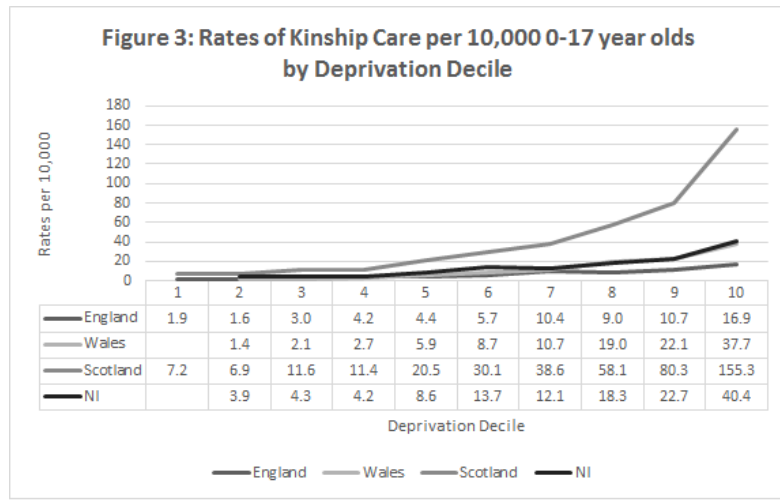

A Spearman's correlation was run to assess the relationship between deprivation and a child living in kinship care. There was a strong positive correlation between deprivation and kinship care which was statistically significant in all four countries (England $r_{s}=.98, p=<.001$, Wales $r_{s}=1.00, p=<.001$, Scotland $\left.r_{s}=.98, p=<.001, N I r_{s}=.98, p=<.001\right)$. However, this pattern could be driven by the established relationship that deprivation has on the chances of a child entering care overall. To account for this, the proportions of kinship use, by deprivation decile as a function of LAC rates overall, were also explored using Spearman's rank correlation tests. 
The results show that for England, kinship care use, as a function of LAC overall, did not show a significant relationship with deprivation ( $r s=-.20, p=.583$ ), with a fairly consistent proportion of kinship care regardless of deprivation. For Scotland, a positive relationship between kinship care use and deprivation was observed, although this relationship did not quite reach statistical significance ( $r s=.62, p=.054)$. This is likely due to a moderation of this relationship for less deprived areas, where deprivation appears to have no clear relationship with kinship care compared to more deprived areas where the pattern is stronger. However, for both Wales and $\mathrm{NI}$, a strong positive relationship was observed between deprivation decile and use of kinship care as a proportion of all LAC (Wales $r s=.87, p=.001 ; \mathrm{NI} r s=.90, p<.001)$.

This may in part relate to overall higher levels of deprivation in these two nations plus the fact that a greater share of the child population in NI and Wales live in more deprived areas (Bywaters and al., 2017). Figure 4 shows the distribution of the child population across the five deprivation quintiles (with quintile five being the most deprived). It shows that both $\mathrm{NI}$ and Wales have very few children living in the least deprived neighbourhoods ( $\mathrm{NI}$, less than one per cent of the child population) but are concentrated in areas of higher deprivation compared to England and Scotland.

Figure 4. Child Population (\%) by Deprivation Quintile, 4 UK Countries 2015

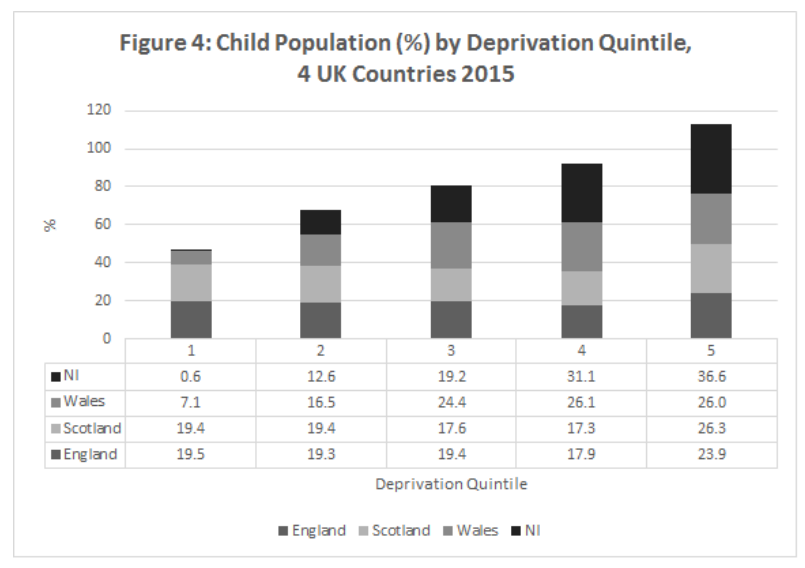




\section{Discussion}

This is the first data since the 2001 census analysis (Nandy and Selwyn, 2012) to confirm the relationship between deprivation and kinship care in the UK. The data demonstrate current evidence for the extensive use of kinship care, and particularly in areas of high deprivation.

\section{Kinship care in NI and Scotland}

Analyses found that the chances of a child becoming looked after by formal kinship carers was much greater in Scotland and NI than in England and Wales. We have acknowledged that this may in part be attributed to variations in definitions of kinship care, intervention thresholds, and individual social work practice. LAC rates in Scotland were generally much higher than the other nations. In Scotland, LAC numbers include children on Compulsory Supervision Orders, many of whom are placed at home with their parents but this does not account for the higher rates of children in kinship care (children living with parents were not included in our analysis). The growing practice of placing children for adoption, or on Special Guardianship Orders (SGOs), in England and Wales, since their introduction in 2006 (Bilson, 2017) may help suppress kinship care rates in the statistics. A comparison of kinship care in England and Ireland found a 'greater reluctance to sever the birth family tie' (Munro and Gilligan, 2013: 187) in NI/Republic of Ireland than England, when adoption was being considered for a child. Adoption rates in $\mathrm{NI}$ remain low (120 children were adopted from care in the year ending 31 March 17 (Community Information Branch, 2017), representing less than five per cent of the LAC population). Bilson (2017) has calculated that in England, in March 2016, more children were in out of home care through adoption $(53,000)$ or SGOs $(20,000)$ than were LAC $(70,000)$. Children subject to an SGO are no longer counted in LAC statistics but the vast majority of SGO applicants have been relatives or family friends (Wade et al., 2014). Although similar legislation in Scotland (permanence orders without authority to adopt) continues to count children as LAC, closer examination of their use did not account for the higher rates observed because the number of POs was relatively small. 
Higher rates in $\mathrm{NI}$ and Scotland may also be affected by cultural traditions. The role that religion plays on finding a suitable placement for a child in $\mathrm{NI}$ may have an impact. The Children (NI) Order places a duty on the HSCTs to ensure that a child is brought up within their existing religious community and this extends to foster care placements, where supply is limited. The main ruling party, the Democratic Unionist Party (DUP), promotes conservative religious views within government policy which has an impact on daily life (Whiting, 2015, Gomez and Tonge, 2016), church attendance remains high, and the education system is largely segregated along religious lines.

Due to the conflict in $\mathrm{NI}$, to some extent, $\mathrm{NI}$ has been subjected to higher levels of state social control than other countries, and has fared much worse economically. In the mid-90s, GDP per head was less than 80 per cent of the UK average, and with high unemployment rates and outward migration, UK government policy levered significant financial assistance to attract inward investment (Harris and Trainor, 2005). Currently, NI has the highest proportion of public sector workers and public spending per head is almost 20 per cent higher than the rest of the UK (Dar, 2013). Economic reliance on the state remains significant and state provision dictates demand for services. The peace dividend in $\mathrm{NI}$ attracted significant funding from Europe which did much to bolster the voluntary sector economy (Racioppi and O'Sullivan See, 2007). This sector has provided an alternative and acceptable source of support for families, particularly in areas where state agencies may have been viewed with suspicion or derision. Although referral rates to children's services are higher in $\mathrm{NI}$ than elsewhere in the UK, intervention rates are lower, suggesting a system that is managing referrals differently. This might be because the threshold for intervention is higher or early intervention initiatives, including Family Support Hubs, are effective (Bunting et al., 2017). Nl's integrated health and social system may have helped cushion services from austerity and full implementation of Universal Credit has been delayed.

To a lesser extent, in Scotland, there has also been evidence of a community response to families in crisis. Since devolution, the Scottish Government has adopted ambitious and modern approaches to tackling social care, in significant contrast to policy elsewhere in the 
UK (Roy et al., 2013), including specific provision for some categories of informal kinship carers. Scotland and Ireland also have lengthy traditions of community care of vulnerable children and extended rural kinship networks that provide labour or facilitate educational opportunities for children outside of the home (Hill et al., 1991, Gray, 2014, Harper, 2015). Analysis of rural communities in $\mathrm{NI}$, in the twentieth century, identified the importance of extended kinship and, since the 1990s, Scotland and Ireland have seen growth in rural repopulation. This is fuelled by return migration, family links (Stockdale, 1992), being 'known' in a familiar community (Laoire, 2007, Ní Laoire, 2007), or is perhaps a response to idealistic representations of rural life, and the lure of a better lifestyle for their families at the birth of children (Valentine, 1997).

\section{Kinship care and area deprivation}

Analysis also found that the use of kinship care was linked to area deprivation in certain parts of the UK. Although there was no significance in the relationship between kinship care and deprivation in England, in Scotland a positive relationship was observed, and in $\mathrm{NI}$ and Wales the relationship was statistically significant. This led to more kinship care placements in the looked after population in deprived areas in $\mathrm{NI}$ and Wales. This may in part relate to overall higher levels of deprivation in these two nations plus the fact that a greater share of the child population in $\mathrm{NI}$ and Wales live in more deprived areas (Bywaters and al., 2017), creating poverty-related demand. When funds are stretched, kinship care not only offers the preferred placement type, it is cost-effective in terms of directing resources with less professional and financial support required, and in many cases provides a suitable placement which is less likely to break down.

Evidence from the qualitative case study strand of the CWIP, (reported elsewhere (Morris et al., 2018)), exploring discourses of poverty in child protection practice, identified a recurrent narrative that social workers had consciously detached themselves from poverty, because they were overwhelmed that it was an issue they could do nothing about. This adds to the quantitative evidence that kinship care poses a dilemma for welfare policy and social 
work practice. Firstly, family policy objectives are considered to have relatively low status in terms of public policy priorities (Hantrais, 2004), the 'rhetoric is supportive of families, but where policy actors are often reluctant to intervene in private life' (Hantrais, 2004: 17).The state refrains from intervening in the private lives of families unless they fail to meet their responsibilities as parents (Cheal, 2008). However, for those children entering kinship care, state intervention is often at arm's length, and not under the same scrutiny of other placement options. Is the rise in kinship care a product of austerity providing best value for money? Our data cannot explain what is rising rates, but current models of kinship care are undeveloped and inappropriately based on non-traditional NRFC (Munro and Gilligan, 2013) and more research is needed to understand why practice varies between the nations.

\section{Conclusion}

This article aims to add to the knowledge and understanding of how kinship care operates within the welfare state and how poverty and deprivation impacts on this group of carers in the UK. It outlines that despite kinship care being treated as the primary placement option for most families, its status in legal, policy and practice terms is unequal and in effect fails to recognise the kinship family setting as a contemporary family alternative.

Given the established relationship between poverty and child abuse and neglect (Bywaters et al., 2016b), the growing and extended use of kinship care potentially poses additional risks for families because they are not afforded equal status. Despite the many benefits of kinship care, these children are disproportionately exposed to deprivation in some parts of the UK. It is vital that a comprehensive model for formal and informal care is developed that provides the necessary preparation, training, and ongoing support for children and carers. Awareness of the risks that poverty exposes families to must be raised in policy and practice to support the social work professional to provide appropriate support to these families.

\section{Acknowledgements}

Funding for the Child Welfare Inequalities Project was provided by the Nuffield Foundation. 
The authors would like to acknowledge the help provided by staff of the Honest Broker Service (HBS) within the Business Services Organisation Northern Ireland (BSO). The HBS is funded by the BSO and the Department of Health for Northern Ireland (DoH). The authors alone are responsible for the interpretation of the data and any views or opinions presented are solely those of the author and do not necessarily represent those of the BSO.

\section{References}

Aldgate, J. (2009) 'Living in kinship care: a child-centred view', Adoption and Fostering, 33, $51-63$.

Andersen, S. H. and Fallesen, P. (2015) 'Family matters? The effect of kinship care on foster care disruption rates', Child Abuse and Neglect, 48, 68-79.

Arts, W. and Gelissen, J. (2002) 'Three worlds of welfare capitalism or more? A state-of-theart report', Journal of European Social Policy, 12, 137-58.

Bailey, S. J., Haynes, D. C. and Letiecq, B. L. (2013) "How can you retire when you still got a kid in school?": Economics of raising grandchildren in rural areas', Marriage and Family Review, 49, 671-93.

Bell, T. and Romano, E. (2017) 'Permanency and safety among children in foster family and kinship care: a scoping review', Trauma, Violence, and Abuse, 18, 268-86.

Berrick, J. D. and Hernandez, J. (2016) 'Developing consistent and transparent kinship care policy and practice: state mandated, mediated, and independent care', Children and Youth Services Review, 68, 24-33.

Breman, R. (2014) Peeling Back the Layers: Kinship Care in Victoria 'Complexity in Kinship Care' - Research Report, Victoria: Baptcare.

Breman, R., Macrae, A. and Vicary, D. (2018) "It's been an absolute nightmare'-family violence in kinship care in Victoria', Children Australia, 43, 7-12.

Brennan, D. and Cass, B. (2014) 'Grandparents as primary carers of their grandchildren', Families, policy and the law, 12,109-18. 
Broad, B. (2004) 'Kinship care for children in the UK: messages from research, lessons for policy and practice', European Journal of Social Work, 7, 211-27.

Brown, S., Cohon, D. and Wheeler, R. (2002) 'African American extended families and kinship care: how relevant is the foster care model for kinship care?' Children and Youth Services Review, 24, 53-77.

Bunting, L., McCartan, C. and Davidson, G. (2017) Identifying and Understanding Inequalities in Child Welfare Intervention Rates: Comparative Studies in Four UK Countries, Single Country Quantitative Study Report: Northern Ireland, Belfast: Nuffield Foundation, Queen's University Belfast.

Bywaters, P. and Al., E. (2017) Identifying and Understanding Inequalities in Child Welfare Intervention Rates: Comparative Studies in Four Countries, Briefing Paper 2: UK Four Country Quantitative Comparison, Coventry: Coventry University.

Bywaters, P., Brady, G., Sparks, T. and Bos, E. (2016a) 'Child welfare inequalities: new evidence, further questions', Child and Family Social Work, 21, 369-80.

Bywaters, P., Brady, G., Sparks, T., Bos, E., Bunting, L., Daniel, B., Featherstone, B., Morris, K. and Scourfield, J. (2015) 'Exploring inequities in child welfare and child protection services: explaining the 'inverse intervention law', Children and Youth Services Review, 57, 98-105.

Bywaters, P., Bunting, L., Davidson, G., Hanratty, J., Mason, W., McCartan, C. and Steils, N. (2016b) The Relationship Between Poverty, Child Abuse and Neglect: An Evidence Review, York, United Kingdom: Joseph Rowntree Foundation.

Bywaters, P., Scourfield, J., Jones, C., Sparks, T., Elliott, M., Hooper, J., McCartan, C., Shapira, M., Bunting, L. and Daniel, B. (forthcoming) 'Identifying and understanding inequalities in child welfare intervention rates: quantitative evidence from a comparison of the four UK countries', Journal of Social Work.

Cheal, D. (2008) Families in Today's World: A Comparative Approach, Oxford: Routledge.

Children Act (1989) Available at: https://www.legislation.gov.uk/ukpga/1989/41 [accessed 24.05.2018]. 
The Children (Northern Ireland) Order (1995) Available at http://www.legislation.gov.uk/nisi/1995/755/contents/made [accessed 24.05.2018].

The Children (Private Arrangements for Fostering) Regulations (2005) Available at: http://www.legislation.gov.uk/uksi/2005/1533/contents/made [accessed 24.05.2018].

Community Information Branch (2017) Children Adopted from Care in Northern Ireland 2016/17, Belfast: Department of Health.

Connolly, M., Kiraly, M., McCrae, L. and Mitchell, G. (2017) 'A kinship care practice framework: using a life course approach, The British Journal of Social Work, 47, 87-105.

Corbin, A. (2015) 'Decreasing disproportionality through kinship care’, Scholar, 18, 73.

Cox, C. (2014) 'Personal and community empowerment for grandparent caregivers', Journal of Family Social Work, 17, 162-74.

Daly, M. and Kelly, G. (2015) Families and poverty: everyday life on a low income, Bristol: Policy Press.

Daly, M. and Perry, G. (2011) 'Has the child welfare profession discovered nepotistic biases?', Human Nature: An Interdisciplinary Biosocial Perspective, 22, 350-69.

Dar, A. (2013) Public Sector Employment and Expenditure by Region, London: House of Commons Library.

Davey, J. (2016) The Care of Kin: A Case Study Approach to Kinship Care in The South of England and Zululand, South Africa, Bournemouth: Bournemouth University.

Davidson, G., Bunting, L., Bywaters, P., Featherstone, B. and McCartan, C. (2017) 'Child welfare as justice: why are we not effectively addressing inequalities?', British Journal of Social Work, 47, 6, 1641-51.

Denby, R.W. (2016) Kinship Care: Increasing Child Well-being through Practice, Policy, and Research, New York: Springer.

Department for Communities and Local Government (2016) The English Indices of Deprivation 2015 - Frequently Asked Questions [Online], Department for Communities and Local Government, https://assets.publishing.service.gov.uk/government/uploads/system/uploads/attachm 
ent data/file/579151/English Indices of Deprivation 2015 -

Frequently Asked Questions Dec 2016.pdf [accessed 01.04.2018].

DHSSPS (2014) Minimum Kinship Care Standards—Northern Ireland, Belfast: Department of Health, Social Services and Public Safety.

Ehrle, J. and Geen, R. (2002) 'Kin and non-kin foster care - findings from a national survey', Children and Youth Services Review, 24, 15-35.

Esping Andersen, G. (1990) The Three Worlds of Welfare Capitalism, Princeton: Princeton University Press.

Farmer, E. (2009) 'What factors relate to good placement outcomes in kinship care?', British Journal of Social Work, 40, 426-44.

Farmer, E. and Moyers, S. (2008) Kinship Care: Fostering Effective Family and Friends Placements, London: Jessica Kingsley Publishers.

Font, S. A. (2015) 'Is higher placement stability in kinship foster care by virtue or design?', Child Abuse and Neglect, 42, 99-111.

Fruhauf, C. A., Pevney, B. and Bundy-Fazioli, K. (2015) 'The needs and use of programs by service providers working with grandparents raising grandchildren', Journal of Applied Gerontology, 34, 138-57.

Geen, R., and Berrick, J. D. (2002) 'Kinship care: an evolving service delivery option’, Children and Youth Services Review, 24, 1-14.

Gomez, R. and Tonge, J. (2016) 'New members as party modernisers: the case of the Democratic Unionist Party in Northern Ireland', Electoral Studies, 42, 65-74.

Gray, J. (2014) 'The circulation of children in rural Ireland during the first half of the twentieth century', Continuity and Change, 29, 399-421.

Guidance on the Looked After Children (Scotland) Regulations 2009 and the Adoption and Children (Scotland) Act 2007 (2011) Available at http://www.gov.scot/Publications/2011/03/10110037/0 [accessed 24.05.2018].

Hantrais, L. (2004) Family Policy Matters Responding to Family Change in Europe, Bristol: The Policy Press. 
Harnett, P. H., Dawe, S. and Russell, M. (2014) 'An investigation of the needs of grandparents who are raising grandchildren', Child and Family Social Work, 19, 411-20.

Harper, M. (2015) 'Boarding out and home and abroad: rescuing and rehabilitating Scotland's destitute children from the 1860s to the 1960s', Northern Scotland, 27, 99-115.

Harris, R. and Trainor, M. (2005) 'Capital subsidies and their impact on total factor productivity: firm-level evidence from Northern Ireland', Journal of Regional Science, 45, 4974.Herring, D. J., Shook, J. J., Goodkind, S. and Kim, K. H. (2009) 'Evolutionary theory and kinship foster care: an initial test of two hypotheses', Capital University Law Review, 38, 291-320.

Hill, M., Murray, K. and Rankin, J. (1991) 'The early history of Scottish child welfare', Children and Society, 5, 182-95.

Hooper, J., Shapira, M. and Daniel, B. (2017) Identifying and Understanding Inequalities in Child Welfare Intervention Rates: Comparative Studies in Four UK Countries. Single Country Quantitative Study Report: Scotland, Stirling: University of Stirling.

Houston, S., Hayes, D. and MacDonald, M. (2017) 'Hearing the voices of kinship foster carers in Northern Ireland: an inquiry into characteristics, needs and experiences', Families, Relationships and Societies, 7, 1, 71-87.

Hunt, J. and Waterhouse, S. (2013) It's Just Not Fair! Support, Need and Legal Status in Family and Friends Care, London: Family Rights Group

Kidner, C. (2012) Kinship Care, SPICe briefing SB 08/03, Edinburgh: The Scottish Parliament. Kiraly, M. (2015) 'A review of kinship carer surveys: the 'Cinderella' of the care system?', Child, Family, Community, Australia (CFCA) Information Exchange, 31, 1-28.

Koh, E. (2010) 'Permanency outcomes of children in kinship and non-kinship foster care: testing the external validity of kinship effects', Children and Youth Services Review, 32, 389-98.

Kreider, R. and Ellis, R. (2011) 'Living Arrangements of Children: 2009', Current Population Reports, Washington, DC: U.S. Census Bureau, https://www.census.gov/prod/2011pubs/p70-126.pdf [accessed 17.05.2018]. 
Kropf, N. P. and Robinson, M. M. (2004) 'Pathways into caregiving for rural custodial grandparents', Journal of Intergenerational Relationships, 2, 63-77.

Lewis, J. (1998) Gender, Social Care and Welfare State Restructuring in Europe, London/Aldershot: Ashgate.

Lin, C.-H. (2014) 'Evaluating services for kinship care families: a systematic review', Children and Youth Services Review, 36, 32-41.

MacDonald, M., Hayes, D. and Houston, S. (2018) 'Understanding informal kinship care: a critical narrative review of theory and research', Families, Relationships and Societies, 7(1), 71-87.

McGhee, J., Bunting, L., McCartan, C., Elliott, M., Bywaters, P. and Featherstone, B. (2017) 'Looking after children in the UK-convergence or divergence?', The British Journal of Social Work, bcx103, https://doi.org/10.1093/bjsw/bcx103.

McGhee, J. and Waterhouse, L. (2012) 'Massachusetts and Scotland: from Juvenile justice to child welfare?', Child Welfare: Journal of the Child Welfare League of America, 91, 169-91.

Messing, J. T. (2006) 'From the child's perspective: a qualitative analysis of kinship care placements', Children and Youth Services Review, 28, 1415-34.

Mitchell, G. (2014) 'Children with disabilities in child and family welfare services', Children Australia, 39, 107-18.

Morgan, D. (2011) Rethinking Family Practices, London: Springer.

Morris, K., Mason, W., Bywaters, P., Featherstone, B., Daniel, B., Brady, G., Bunting, L., Hooper, J., Mirza, N., Scourfield, J. and Webb, C. (2018) 'Social work, poverty, and child welfare interventions', Child and Family Social Work, https://doi.org/10.1111/cfs.12423.

Munro, E. R. and Gilligan, R. (2013) 'The 'dance' of kinship care in England and Ireland: navigating a course between regulation and relationships', Psychosocial Intervention, 22, 185-92. 
Nandy, S. and Selwyn, J. (2012) 'Kinship care and poverty: using census data to examine the extent and nature of kinship care in the UK', British Journal of Social Work, 43, 164966.

Ní Laoire, C. (2007) 'The 'green green grass of home'? Return migration to rural Ireland', Journal of Rural Studies, 23, 332-44.

O'Leary, M. and Butler, S. (2015) 'Caring for grandchildren in kinship care: what difficulties face Irish grandparents with drug-dependent children?', Journal of Social Work Practice in the Addictions, 15, 352-72.

Payne, R. A. and Abel, G. A. (2012) 'UK indices of multiple deprivation-a way to make comparisons across constituent countries easier', Health Statistics Quarterly, 22.

Peterson, T. L. and Starks, S. H. (2014) 'The contextual experiences of rural custodial grandparents and opportunities for social work', Journal of Family Social Work, 17, $175-88$.

Probst, J., Moore, C., Glover, S. and Samuels, M. (2004) 'Person and place:

the compounding effects of race/ethnicity and rurality on health', American Journal of Public Health, 94, 1695-03.

Racioppi, L. and O'Sullivan See, K. (2007) 'Grassroots peace-building and third-party intervention: the European Union's special support programme for peace and reconciliation in Northern Ireland', Peace and change, 32, 361-90.

Roy, M. J., Donaldson, C., Baker, R. and Kay, A. (2013) 'Social enterprise: new pathways to health and well-being?', Journal of Public Health Policy, 34, 55-68.

Ryan, J., Hong, J., Herz, D. and Hernandez, P. (2010) 'Kinship foster care and the risk of juvenile delinquency', Children and Youth Services Review, 32, 1823-30.

Sakai, C., Lin, H. and Flores, G. (2011) 'Health outcomes and family services in kinship care: analysis of a national sample of children in the child welfare system', Archives of Pediatrics and Adolescent Medicine, 165, 159-65. 
Scottish Government (2015) Kinship Care, Edinburgh: Scottish Government, https://beta.gov.scot/policies/looked-after-children/kinship-care/ [accessed 04.04.2018].

Selwyn, J., Farmer, E., Meakings, S. and Vaisey, P. (2013) The Poor Relations? Children and Informal Kinship Carers Speak Out, University of Bristol in partnership with Buttle UK.

Selwyn, J. and Nandy, S. (2014) 'Kinship care in the UK: using census data to estimate the extent of formal and informal care by relatives', Child and Family Social Work, 19, 4454.

Stockdale, A. (1992) 'State intervention and the impact on rural mobility flows in Northern Ireland', Journal of Rural Studies, 8, 411-21.

Taussig, H. N. and Clyman, R. B. (2011) 'The relationship between time spent living with kin and adolescent functioning in youth with a history of out-of-home placement', Child Abuse and Neglect, 35, 78-86.

Testa, M., Bruhn, C. M. and Helton, J. (2010) 'Comparative safety, stability, and continuity of children's placements in formal and informal substitute care', in M.B. Webb, K. Dowd, B. Jones Harden, J. Landsverk and M. Testa (ed.), Child welfare and Child Well-Being: New Perspectives from the National Survey of Child and Adolescent Well-Being, Oxford: Oxford University Press.

United Nations (1989) Convention on the Rights of the Child, http://www.unicef.org.uk/wpcontent/uploads/2010/05/UNCRC united nations convention on the rights of the child.pdf [accessed 17.11.2017].

Valentine, G. (1997) 'A safe place to grow up? Parenting, perceptions of children's safety and the rural idyll', Journal of rural studies, 13, 137-48.

Wade, J., Sinclair, I., Stuttard, L. and Simmonds, J. (2014) Investigating Special Guardianship: Experiences, Challenges and Outcomes, London: Department of Education.

Weeks, J., Heaphy, B. and Donovan, C. (2003) Same Sex Intimacies: Families of Choice and Other Life experiments, London: Routledge. 
Walsh, J. and Mason, W. (2018) 'Walking the walk: changing familial forms, government policy and everyday social work practice in England', Social Policy and Society, [doi to be inserted].

Wellard, S., Meakings, S., Farmer, E. and Hunt, J. (2017) Growing Up in Kinship Care, Experiences as Adolescents and Outcomes in Young Adulthood, London: Grandparents Plus.

Whiting, S. (2015) ‘Between money and morality: how would Northern Ireland's DUP approach post-election deal-making?', Juncture, 21, 287-90.

Winokur, M. A., Holtan, A. and Batchelder, K. E. (2018) 'Systematic review of kinship care effects on safety, permanency, and well-being outcomes', Research on Social Work Practice, 28, 19-32.

Zuravin, S. J., Benedict, M. and Somerfield, M. (1993) 'Child maltreatment in family foster care', American Journal of Orthopsychiatry, 63, 589-596. 